\title{
第70回日本循環器学会学術集会
}

1.メタボリックシンドロームの分子機序と治療の最前線

\section{冠疾患における高中性脂肪血症の重要性 一レムナントリポ蛋白の代謝と動脈硬化惹起性}

\section{はじめに}

冠動脈疾患のもっとも強い危険因子は，低比重 リポ蛋白 (low-density lipoprotein: LDL)ーコレス テロールが高值であるという疫学データ，その酸 化変性がマクロファージの泡沫化や炎症を招い て動脈硬化巣を形成促進するという説，そして LDL-コレステロール值を低下させることの重要 性が，多くのエビデンスによって支持されてい る.

しかし，冠疾患を起こした患者の病態を検討し てみると，とくにわれわれ日本人においてすべて の例が高 LDL コレステロール血症を呈している わけではなく, 加齢や性別, 契煙に加えて, 高中 性脂肪（トリグリセリド）血症，糖代謝異常や高 血圧など多因子からなる代謝異常を有している例 が多いことがわかった。このようにして内蔵肥満 と高脂血症, 高血压, 耐糖能異常を呈する病態を 冠動脈疾患の高リスク患者として認識する必要性 が高まり，メタボリックシンドロームとして診断 基準が提唱されることになった1).

メタボリックシンドロームや糖代謝異常でみら れる脂質異常の特徵に，レムナントリポ蛋白（以 下レムナント）の増加がある．本稿ではレムナン トの動脈硬化䒩起性について述べる.
神戸学院大学栄養学部栄養生理学

神戸大学医学部保健学科

神戸大学大学院医学系研究科循環呼吸器病態学
藤岡由夫

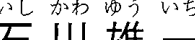
西机雄 横山光宏
日本人のメタボリックシンドロームの 実態

2006 年 5 月に発表された厚生労働省の平成 16 年国民健康・栄養調査結果の概要によると，40 歳を境に日本でメタボリックシンドロームの診断 基準を満たす者の割合が急増し，40〜 74歳の男 性では，有病者は $25.7 \%$ ，女性は $10 \%$ に達してい るという。該当者は全国で約 940 万人，予備群も 併せると約 1,960 万人と推計されている.

端野・壮瞥町研究では, メタボリックシンド ロームを呈する者の心血管イベントは非メタボリ ックシンドロームの者と比べて高いことが明らか になり，この調査では代謝異常の中で高血圧の合 併率がもっとも高かった ${ }^{1,2)}$ ．一方，2000年にお ける12,839名の通院していない日本人を対象にし た高脂血症の実態調査が行われ，その中で 3,264 名を解析したメタボリックシンドロームの頻度も 報告されている3)。この調查によれば, 男性 1,917 名中 $12.1 \%$ ，女性 1,347 名中 $1.7 \%$ で，全体では $7.8 \%$ であった，対象集団の特徵や検查方法によ って頻度の差は生じるであろう。このようにメタ ボリックシンドロームは，冠疾患の予防や治療の 対象として重要な病態であることがわかる.

[Key words $]$ レムナント, 中性脂肪（トリグリセリド)，RLP，メタボリックシンドローム，動脈硬化 
動脈硬化惹起性をもつ高トリグリセリド 血症

1979年にZilversmitによって食後高脂血症の 概念が提唱されて以来, 食事量とその内容によっ て血清脂質值に影響が出て動脈硬化発症につなが ることが，数多くの報告から支持されている.し かしながら, 食事由来の脂質が直接的に動脈硬化 病巣形成に関与するかどうかは, 高トリグリセリ ド血症がさまざまな原因で起こることや，食後脂 質値の変動の個体差が大きいなどの理由で明らか ではなかった，すなわち, 食事由来のリポ㔻白で あるカイロミクロンとカイロミクロンレムナント が動脈硬化発症に直接的に関与するかどうか, 長 年論議されているのが現状であった.

とくにカイロミクロンは大きな粒子であるため 血管壁に侵入することは不可能であり, アポ蛋白 C-II 欠損症やリポ蛋白リパーゼ (lipoprotein lipase: LPL) 欠損症などの先天性の高力イロミク ロン血症では動脈硬化性疾患はまれである.アル コール性, 原発性胆汁性肝硬変やネフローゼ症候 群などでも高トリグリセリド血症が認められる が，実際に動脈硬化性疾患を起こしやすい高トリ グリセリド血症を呈する病態は, 糖代謝異常やメ タボリックシンドロームであり，これらの病態か どうかを鑑別することが大切である。

\section{高トリクリセリド血症の発症機序と レムナントの代謝}

血中トリグリセリド值の上昇をきたす機序を考 えると，まず脂肪の摂取過多や，小腸に打汀るア ポB48 合成立進と分泌されるカイロミクロンの 増加が考えられる4). そして耐糖能異常やインス リン不足によって，LPLの合成抒よび活性の低 下をきたすことによるトリグリセりド分解量の減 少, 肝臓や各組織でのリポ蛋白取り込み低下, 肝 蔵や脂肪組織におけるトリグリセリド合成分泌立 進などが原因として考えられる。

小腸から作られるカイロミクロンとそのトリグ
リセリドが加水分解されて小さくなったカイロミ クロンレムナント（狭義のレムナント）, 肝臓か ら分泌される超低比重リポ蛋白（very-low-density lipoprotein: VLDL) とVLDL レムナント（中 間比重リポ蛋白, IDL) といったトリグリセリ ド・リッチなリポ蛋白の血液中の停滞が起こり, 食後のみならず空腹時でも血中トリグリセリド值 の上昇を認めることになる、レムナントとは「遺 残物」という意味であるが，血中トリグリセリド 値が正常範用や軽度上昇の範囲に留まっていて も，レムナントが上昇している場合がある.

食事由来のリポ蛋白であるカイロミクロンが肝 蔵に取り込まれるためには, デェッセ腔に侵入し 肝細胞に取り込まれるサイズまで小さくなる，す なわち LPLによるトリグリセリドの加水分解が 必要である4)(図 1 )。その間に，アポCを失い, リゾリン脂質やアポ $\mathrm{E} か ゙$ 増え, コレステロール 転送蛋白 (CETP) の作用で含有されるコレステ ロールも增える5（図 2）。一粒子当たりのコレ ステロール含量は LDLより多いとされている。

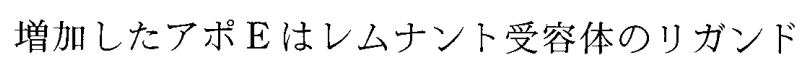
として働く、肝蔵においてレムナントを取り込む 受容体は，主にLDL受容体と考えられている が，その他 LDL 受容体関連蛋白 (LRP)，アポ B48受容体など数多く報告されており，それらを 総称してレムナント受容体と呼んでいる.プロテ オグリカンや肝性リパーゼもその結合を修飾して 促進する．マクロファージも，後述するようにレ ムナントを取り込むことができる4).

レムナントが増えている場合，CETPの作用 によって，レムナントのようなトリグリセリド 。 リッチなリポ蛋白と LDL との間でトリグリセリ ドとコレステロールエステルの交換が起こり，そ の結果 small dense LDL が増加する. small dense LDL も強い動脈硬化惹起性をもつため, 低 HDL コレステロール血症, 高レムナント血症, 高 small dense LDL 血症が, 耐糖能異常やメタボリ ックシンドロームでは重なっている状態になって いると考えられる. 


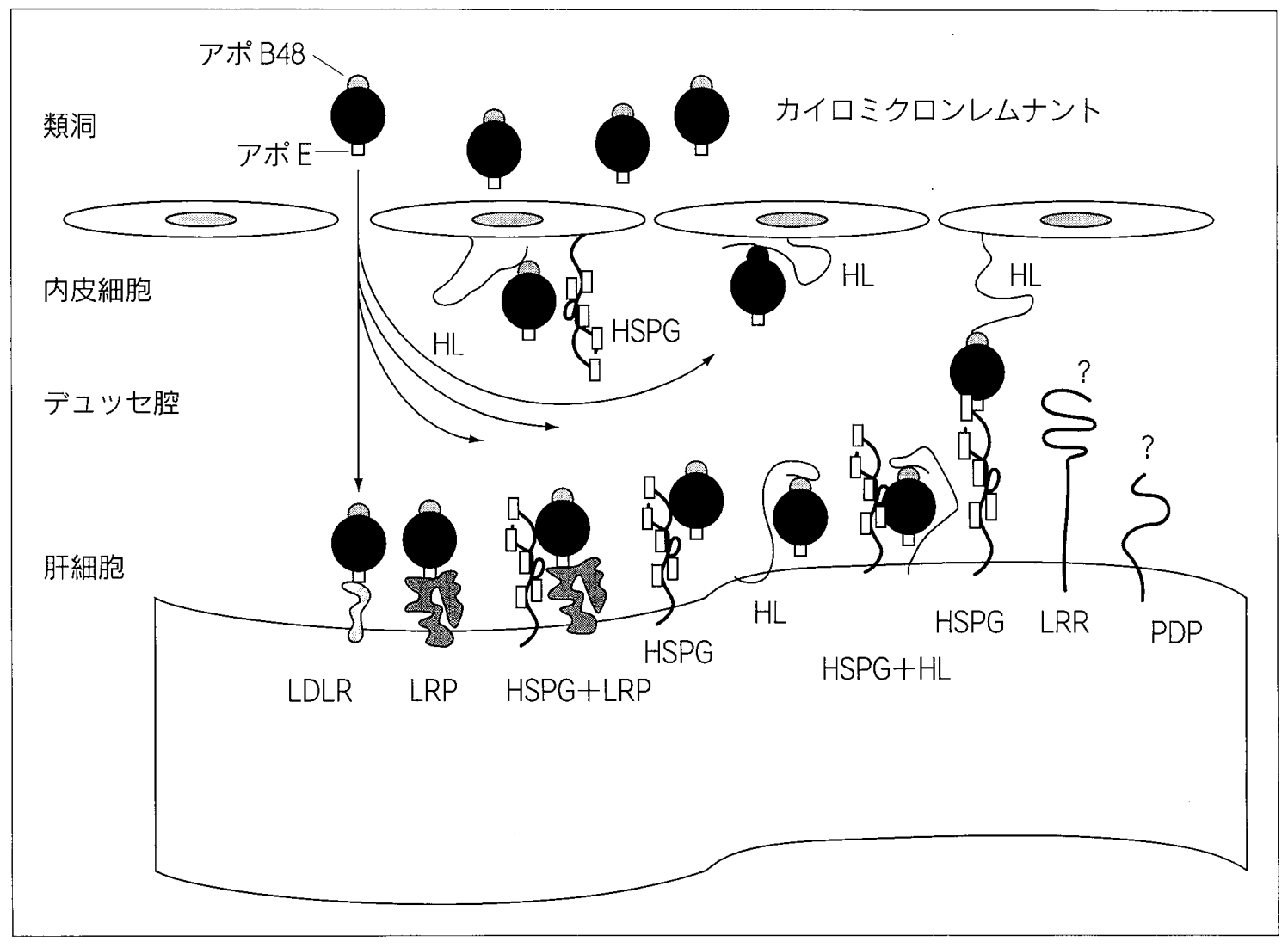

図 1 肝臓でのカイロミクロンレムナントの取り込み機構

(文献 4 より引用, 改変) HL : 肝性リパーゼ, HSPG : ヘパラン硫酸プロテオグリカン, LDLR : LDL 受容体, LRP : LDL 受容体関連 蛋白, LRR : その他の lipoprotein-remnant 受容体, PDP : phospholipolysis 依存珄経路

\section{臨床におけるレムナントの意義}

血中レムナント值を近似的に定量測定できるも のとして，レムナント様粒子 RLP コレステロー ル (RLP-C) 測定法がある. Framingham 研究 をはじめ, 動脈硬化性疾患患者や糖尿病患者など で RLP-C の上昇することが報告されている，実 際に2005年に神戸大学病院循環器内科に入院さ れた冠疾患患者のうち，メタボリックシンドロー ムの患者 $(n=74)$ では非メタボリックシンドロー 厶の患者 $(n=164)$ と比較して RLP コレステロー ルが有意に高値であった $(9.6 \pm 5.8 \mathrm{mg} / \mathrm{d} l$ vs 6.2 $\pm 2.9 \mathrm{mg} / \mathrm{d} l$, mean $\pm \mathrm{SD}$, Student's $t$ 検定, $p<$ 0.0001 ，未発表データ). また, 75 gOGTT で評 価した境界型の耐糖能異常患者でも，糖尿病患者 と同程度に高レムナント血症の割合が高くなるこ
とが報告されている6).この結果から動脈硬化危 險因子としてレムナントの上昇が，耐糖能異常の 段階から大血管障害がすでに生じてくるといわれ ている原因の 1 つになっている可能性がある.

Nakamura らの報告によると，メタボリックシ ンドローム患者で，レムナント高値，そして併せ て高感度 CRP の高値を示す患者は冠動脈疾患の 高リスクを負っている7)，冠疾患を起こしやすい 家族性複合型高脂血症や家族性 III型高脂血症もレ ムナント高値が認められることから，レムナント の上昇は，冠動脈疾患と強く関連していることが わかる。

\section{レムナントの動脈硬化発症機序}

レムナントは動脈硬化の発症や進展にさまざま 


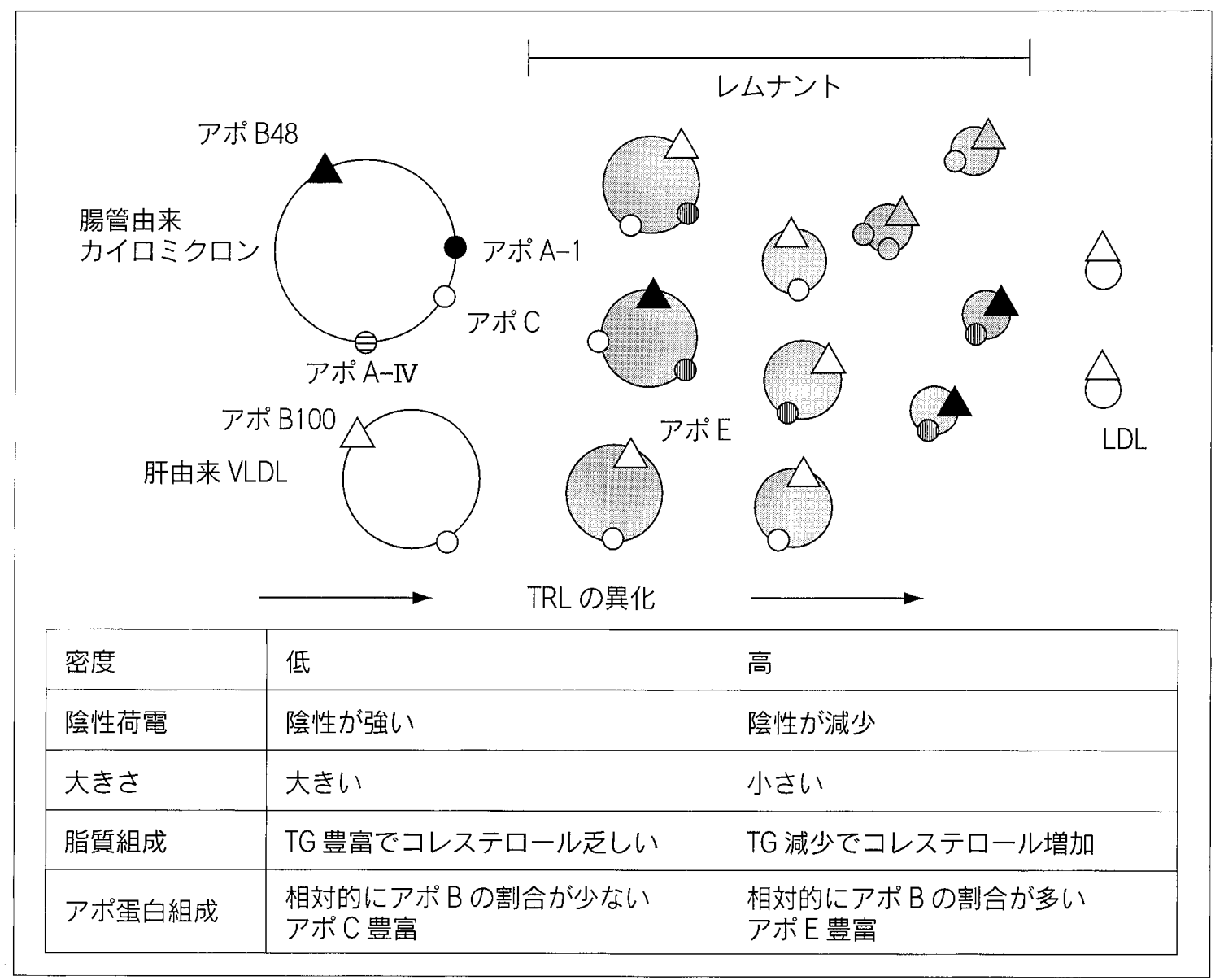

図 2 レムナントの特徵

TRL：トリグリセリド・リッチリポ蛋白, TG：トリグリセリド

な点で関与している.

\section{1. レムナントの血管壁内侵入とマクロファー 渇沫化}

レムナントが直接的に動脈硬化発症に関わるた めには，レムナントが血管壁に侵入することが必 要である。これまで, カイロミクロンや VLDL はその大きさのために血管壁に侵入できないとさ れ，小さな粒子である LDL や HDL だけが注目 されてきたが，小さくなったレムナントは，血管 内に侵入できるサイズをでになると考えられ，動 脈硬化性血管から実際にレムナントの特徽をもつ リポ蛋白が抽出されていることや，実験的に血管 壁に侵入していることを直接証明した報告があ $ろ^{8,9)}$.
血管壁に侵入したレムナントは，マクロファー ジを泡沫化させることができる，われわれは，酸 化やその他変性を加えないフレッシュな状態の力 イロミクロンレムナントが, 正常マウス, LDL

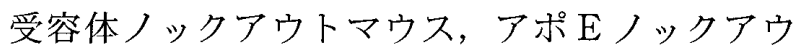
トマウスからの腹腔マクロファージを泡洙細胞に することを確認した ${ }^{10)}$ 、マクロファージは数多 くのレセプターをもつが, native のカイロミクロ ンレムナントの取り込みにおいては，これまでの われわれを含めた諸家の報告で，LDL受容体が 全取り込み量の $50 \%$ 程度を占めるように主な役 割を担っており，重要な点は肝臓と同様，リガン ドとしてアポEがリポ蛋白に多く含まれること である、マクロファージ側からのアポEの分泌 がなくても，取り込みは起こる，その他，LRP 


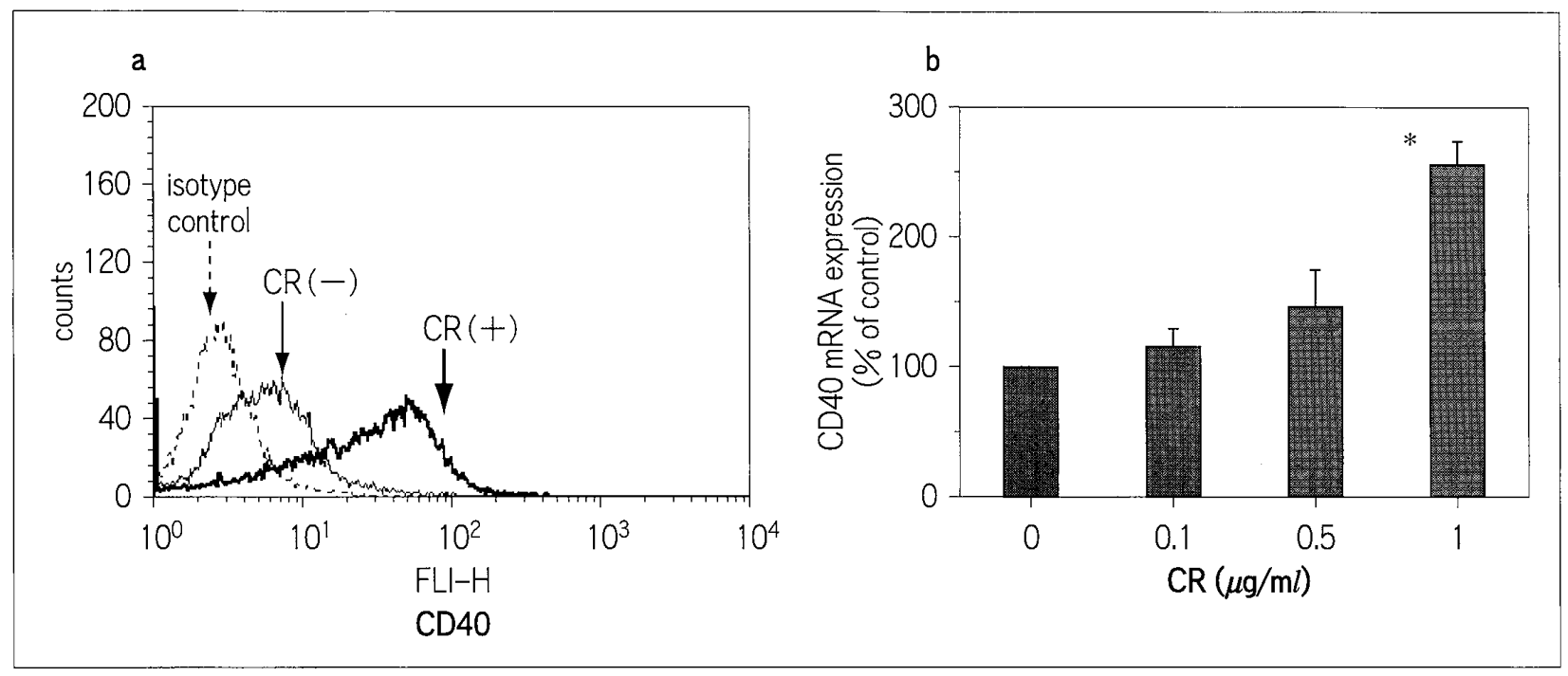

図 3 カイロミクロンレムナントによる CD40 発現宇進

$\mathrm{a}$ ：カイロミクロンレムナント刺激により，THP-1 細胞表面の CD40 発現が元進した. b : THP-1 細胞において CD40 の mRNA 発現がえ進した.

$\mathrm{CR}$ : カイロミクロンレムナント, ${ }^{*} p<0.05$ vs the controls, by ANOVA with Bonferroni/Dunn test

（文献16より引用，改変）

やその他の受容体も加わり，アポ $\mathrm{E}$ 非依存性の 取り込み機構の存在も示唆されている. 少なくと も native のカイロミクロンレムナントの取り込 みには，スカベンジャー受容体の関与は重要でな い.

また，取り込まれたリポ蛋白中のコレステロー ルの細胞外排出が，変性 LDL と同様にトリグリ セリド・リッチなリポ蛋白の刺激で低下し、コレ ステロール蓄積に傾くことも報告されている ${ }^{11)}$.

\section{2. 接着分子と炎症}

リンパ球や単球など，炎症に関わる細胞が血管 壁内に侵入するために接着分子の発現が重要な 役割を担っているが，Doi らによって内皮細胞を RLP で刺激すると，ICAM-1，VCAM-1，tissue factor の発現がえ進することが報告されている12). また, monocyte-chemoattractant protein (MCP1）は単球を血管壁内に侵入させるうえで重要な 役割を担っているが，われわれはラット血管平滑 筋培養細胞においてレムナント刺激が MCP-1 分 泌を時間依存性および濃度依存性にえ進すること を認めている．MCP-1 発現え進の機序としてレ
ムナント刺激は ERK1/2 と p 38 MAP kinase を 活性化させ，それぞれの経路の阻害薬の効果か ら, p38 MAP kinase pathway が必要であること が示唆された ${ }^{13)}$.

レムナントの刺激は, さまざまな炎症性反応機 転を引き起こす．われわれはカイロミクロンレム ナントで， NF- $\mathrm{kB}$ の活性化を介した IL-1 $1 \beta$ の産 生六進 ${ }^{14)}$ ，また，血管壁細胞の増殖，分化，アポ トーシスに関わり，炎症機序にも大きく関わって いる転写因子でめる The early growth response gene-1（Egr-1）の産生元進 ${ }^{15)}$, TNFレセプター ファミリーでB細胞の活性化や分化に関わる CD40の産生立進などを報告している16（図 3 ）.

\section{3. 血栓形成}

高トリグリセリド血症や高レムナント血症では, 以前から血栓形成や凝固能の亢進状態にあること がいわれているが, in vitroでも血管内皮細胞に 掞いて VLDL 刺激が plasminogen activator inhibitor (PAI)-1 産生を六進することが報告されて いる. カイロミクロンレムナントも, MAP pathway, $\mathrm{NF}-\kappa \mathrm{B}$, そして redox-sensitive mechanism 
を介して PAI-1 産生を六進させる17)。

\section{4. 細胞増殖とアポトーシス}

レムナントは, 高濃度では内皮細胞をアポトー シスに陥らせる18)。一方, Kawakami らは, 平 滑筋細胞の増殖を引き起こすことを報告してい $る^{19)}$ ．レムナントが血管平滑筋細胞の増殖と内 皮細胞の障害をきたし，動脈硬化を促進すること が示唆される，実際に高レムナント血症では，プ レチスモグラフィーを用いて検討した内皮依存性 の血管拡張反応が低下していた ${ }^{20)}$.

\section{おわりに}

このように，レムナントは単に脂質を細胞に供 給するだけでなく，炎症の誘導や血栓形成などさ まざまな生理活性を発揮することにより，直接的 にも間接的にも動脈硬化促進に作用することが考 えられる。

今後, メタボリックシンドロームの冠疾患発症 抑制に対して，レムナントを診断や治療のターゲ ットとして考えていく必要があると考えられる。

\section{文}

1）メタボリックシンドローム診断基準検討委員会：メタ ボリックシンドロームの定義と診断基準。日内会誌 2005; 94: 794-809

2）島本和明，三浦哲嗣：メタボリックシンドロームの主 要疾患：高血纴．最新医 2006; 61: 1302-1311

3) Arai H, Yamamoto A, Matsuzawa Y et al: Prevalence of metabolic syndrome in the general Japanese population in 2000. J Atheroscler Thromb 2006; 13: 202-208

4) $\mathrm{Yu} \mathrm{KC}$, Cooper AD: Postprandial lipoproteins and atherosclerosis. Front Biosci 2001; 6: D332-D354

5) Cohn JS, Marcoux C, Davignon J: Detection, quantification, and characterization of potentially atherogenic triglyceride-rich remnant lipoproteins. Arterioscler Thromb Vasc Biol 1999; 19: 2474-2486

6) Watanabe N, Taniguchi $\mathrm{T}$, Taketoh $\mathrm{H}$ et al: Elevated remnant-like lipoprotein particles in impaired glucose tolerance and type 2 diabetic patients. Diabetes Care 1999; 21: 152-156

7) Nakamura $T$, Takano H, Umetani $K$ et al: Remnant lipoproteinemia is a risk factor for endothelial vasomotor dysfunction and coronary artery disease in metabolic syndrome. Atherosclerosis 2005; 181: 321-327

8) Rapp JH, Lespine A, Hamilton RL et al: Triglyceriderich lipoproteins isolated by selected-affinity antiapolipoprotein B immunosorption from human atherosclerotic plaque. Arterioscler Thromb 1994; 14: 17671774

9) Mamo JC, Proctor SD, Smith D: Retention of chylomicron remnants by arterial tissue: importance of an efficient clearance mechanism from plasma. Atherosclerosis 1998; 141 (Suppl 1): S63-S69

10) Fujioka $Y$, Cooper AD, Fong LG: Multiple processes are involved in the uptake of chylomicron remnants by mouse peritoneal macrophages. J Lipid Res 1998; 39: 2339-2349

11) Palmer AM, Murphy N, Graham A: Triglyceride-rich lipoproteins inhibit cholesterol efflux to apolipoprotein (apo) A1 from human macrophage foam cells. Atherosclerosis $2004 ; 173: 27-38$

12) Doi H, Kugiyama K, Oka $\mathrm{H}$ et al: Remnant lipoproteins induce proatherothrombogenic molecules in endothelial cells through a redox-sensitive mechanism. Circulation $2000 ; 102: 670-676$

13) Domoto $K$, Taniguchi $T$, Takahashi $T$ et al: Chylomicron remnants induce monocyte chemoattractant protein-1 expression via p38 MAPK activation in vascular smooth muscle cell. Atherosclerosis 2003; 171: 193-200

14) Okumura $T$, Fujioka $Y$, Morimoto $S$ et al: Chylomicron remnants stimulate release of interleukin $-1 \mathrm{~b}$ by THP1 cells. J Atheroscler Thromb 2006; 13: 38-45

15) Takahashi $Y$, Fujioka $Y$, Takahashi $T$ et al: Chylomicron remnants regulate early growth response factor-1 in vascular smooth muscle cells. Life Sci 2005; 77: $670-682$

16) Kamemura K, Fujioka $Y$, Takaishi $\mathrm{H}$ et al: Chylomicron remnants upregulate CD40 expression via the ERK pathway and a redox-sensitive mechanism in THP-1 cells. Atherosclerosis 2006; 187: 257-264

17) Morimoto S, Fujioka $\mathrm{Y}$, Hosoai $\mathrm{H}$ et al: The reninangiotensin system is involved in the production of plasminogen activator inhibitor type 1 by cultured endothelial cells in response to chylomicron remnants. Hypertens Res 2003; 26: 315-323

18) Kawasaki S, Taniguchi T, Fujioka $Y$ et al: Chylomicron remnant induces apoptosis in vascular endothelial cells. Ann N Y Acad Sci 2000; 902: 336-341

19) Kawakami A, Tanaka A, Nakano $T$ et al: Stimulation 
of arterial smooth muscle cell proliferation by remnant lipoprotein particles isolated by immunoaffinity chromatography with anti-apo A-I and anti-apo B-100. Horm Metab Res 2001; 33: 67-72
20) Okumura T, Fujioka $Y$, Morimoto $S$ et al: Eicosapentaenoic acid improves endothelial function in hypertriglyceridemic subjects despite increased lipid oxidizability. Am J Med Sci 2002; 324: 247-253

\section{用語解説}

\section{インバースアゴニスト}

ある種の $\mathrm{G}$ 蛋白質共役型受容体がアゴニ ストの存在しない状態でも自律的活性を示す こと,さらにこのような受容体の自律的活性 を抑制する薬剂が存在することが明らかとな っている.このようなアゴニストに依存しな い受容体の自律的活性の抑制機構を従来のア ンタゴニストの概念では説明できないことか ら，インバースアゴニストの概念が提唱され るようになった。インバースアゴニストは受 容体に作用して不活性型の構造に維持するこ とで，アゴニストによる受容体の活性化のみ ならず，受容体の自律的活性あるいはアゴニ ストに依存しない受容体の活性化を抑制す る. 対照的に, アンタゴニストはアゴニスト による受容体の活性化は競合的に抑制するも のの，受容体の自律的活性やアゴニストに依 存しない受容体の活性化を抑制することがで きない。

従来の受容体理論によると, 受容体は不活 性型： $\mathrm{R}$ と活性型： $\mathrm{R}^{*}$ との間の平衡状態に あるとされ，アゴニストは $\mathrm{R}^{*} と の$ 高親和性
を示すので，アゴニストが存在すると平衡関 係が $\mathrm{R}^{*}$ ヘシフトし $\mathrm{R}^{*}$ の割合が増加する。 逆に，インバースアゴニストは $\mathrm{R}$ との親和 性が高く，インバースアゴニストが存在する と平衡関係が $\mathrm{R}$ 側へシフトする結果， $\mathrm{R}^{*}$ は 減少し R が増加する。

アンジオテンシン II タイプ1（AT1）受 容体の活性化が，伸展刺激というメカニカル ストレスによってアゴニスト非依存的に生 じ，このようなメカニカルストレスによる受 容体の活性化が心肥大形成に深く関与するこ とが報告されている：また，ある種の AT1 受容体ブロッカーはインバースアゴニストと して作用し，受容体の自律的活性や伸展刺激 による活性化を抑制する．AT1受容体ブロ ッカーのインバースアゴニスト活性の臨床的 意義は現在のところ詳細は不明であるが，臓 器保護作用を左右する重要な薬理学的特性で める可能性が高い。

(千葉大学大学院医学研究院心血管病態解析学. 循環病態医科学 赤澤 空，小室一成） 